\title{
Akt and Erk signal transduction pathways are early markers of differentiation in dominant and subordinate ovarian follicles in cattle
}

\author{
K E Ryan, S M Casey, M J Canty, M A Crowe, F Martin ${ }^{1}$ and A C O Evans
}

School of Agriculture, Food Science and Veterinary Medicine, and ${ }^{1}$ School of Biomolecular and Biomedical Science, College of Life Science, Conway Institute for Biomolecular and Biomedical Research, University College Dublin, Belfield, Dublin 4, Ireland

Correspondence should be addressed to A C O Evans, UCD Agriculture and Food Science Centre, University College Dublin, Belfield, Dublin 4, Ireland; Email: alex.evans@ucd.ie

\begin{abstract}
Dominant follicles are those that continue to develop and have the potential to ovulate while subordinate follicles regress. Characteristics of dominant follicles include a larger diameter, higher intrafollicular estradiol, and lower IGF-binding protein (IGFBP)-4 concentrations compared with other cohort follicles. Follicle development is regulated by endocrine hormones that act via intracellular signaling pathways. Here, we show the differences in Akt, Erk, c-Jun $\mathrm{N}$-terminal protein kinase, and p-38 signaling pathways between dominant and subordinate follicles at the dominance stage of the follicle wave. However, earlier in the follicle wave (dominant follicle selection), there were only differences in the levels of Akt and Erk signal transduction proteins among dominant and subordinate follicles. Using this profile of Akt and Erk protein expression in granulosa and theca cells of selected dominant follicles compared with subordinate follicles, we suggest a predictive model to identify future dominant and subordinate follicles from the pool of otherwise similar cohort follicles at the time of follicle wave emergence. We conclude that the Erk and Akt signal transduction pathways are important for dominant follicle selection and development and, furthermore, that the observed differences in these pathways mark the future dominant follicle from subordinate follicles before differences in follicular diameter, follicular fluid estradiol, and IGFBP-4 concentrations are apparent.
\end{abstract}

Reproduction (2007) 133 617-626

\section{Introduction}

In cattle, ovarian follicle development is characterized by two or three successive waves of follicular growth in each estrous cycle (Savio et al. 1988, Sirois \& Fortune 1988, Ginther et al. 1989). Recruitment of each new wave is preceded and triggered by a transient rise in circulating follicle-stimulating hormone (FSH) concentrations (Adams et al. 1992). Following emergence, follicles continue to develop in parallel until the growth of one follicle rapidly increases and the follicle becomes dominant and the remaining follicles regress, which are termed subordinate follicles (Ginther et al. 1999). After selection, the dominant follicle is typically characterized by a larger diameter, higher follicular fluid concentrations of estradiol, insulin-like growth factor-binding protein (IGFBP) protease activity and free IGF, and lower IGFBP-4 concentrations (Mihm et al. 2000, Fortune et al. 2004). It seems probable that these functional differences occur as a result of internal changes within the follicles while they remain indistinguishable from one another (Fortune et al. 2004). While the exact mechanism by which selection of the dominant follicle and regression of the subordinate follicles occur remains unknown, the inherent ability of the dominant follicle to withstand the decline in FSH concentrations and atresia is a critical factor in determining its continued development. It has long been established that successful follicular development is reliant on the gonadotropins, FSH and luteinizing hormone (LH; Gong et al. 1996, Evans et al. 1997, Mihm et al. 1997, Ginther et al. 1998). Additionally, the importance of intrafollicular factors, such as growth factors and other regulatory proteins, that can modulate the action of the gonadotropins and other growth factors (e.g. IGF and IGF-binding proteins) has also been shown (Fortune et al. 2004).

Gonadotropins and growth factors mediate their biological effects through binding to cell surface receptors, which results in enzymatic phosphorylation cascades (signal transduction pathways) that transmit signals from 
outside the cell to the nucleus. One major survival pathway involves the activation of Akt (protein kinase B), a serine/threonine kinase which is a common mediator of cell survival and proliferation. Activation of the Akt pathway causes general inhibition of pro-apoptotic factors, such as the forkhead transcription factors, Bad and caspase 9, all of which are known to mediate apoptosis (Brunet 1999, Datta et al. 1999, Cardone 2000). Another group of serine/threonine kinases are the mitogen-activated protein kinases (MAPKs). The three most characterized pathways of the MAPK group are the extracellular-regulated kinase (Erk), c-Jun N-terminal protein kinase (JNK), and p-38 pathways. The Erk pathway regulates cell proliferation, differentiation, and survival. The JNK and p-38 pathways are activated in response to cytokines, growth factors, and a variety of environmental stresses. They have been shown to be involved in development, immune responses, and both cell survival and apoptosis with the specific cell response depending on the cellular context (i.e., the type of stimulus, duration of stimulus, cell type, and any additional signaling pathways; Lin 2002, Zhang \& Liu 2002). When activated, these pathways have a diverse array of targets that include cytoskeletal proteins, other kinases, cytoplasmic enzymes, and transcription factors in the nucleus (Pearson et al. 2001, Bogoyevitch et al. 2004, Roux \& Blenis 2004). The pattern of ovarian follicle development during menstrual cycles is also wave-like (Baerwald et al. 2003a, 2003b) and understanding the intracellular signal transduction pathways that regulate follicle selection and atresia may highlight potential targets to regulate ovarian function.

While the roles of MAPK and Akt signal transduction pathways have been extensively studied in numerous cell model systems, their role in ovarian follicle selection and development has not been studied in detail. However, in a preliminary study, we have demonstrated the differences in the levels of Erk and Akt proteins as indicated by immunoblotting between dominant and subordinate follicles in sheep (Evans \& Martin 2000). In the present study, we tested the hypothesis that before morphological dominance, one follicle per cohort (putative future dominant follicle) has higher levels of multiple signal transduction pathway proteins than the other follicles of the cohort (putative future subordinate follicles).

\section{Materials and Methods}

\section{Follicle collection}

In order to investigate differences in signal transduction pathways among dominant and subordinate follicles, four separate experiments were conducted. Experiments 1-3 examined differences among dominant and subordinate follicles in the levels of Akt and members of the MAPK family of kinases (Erk, JNK, and P-38). The fourth experiment examined the levels of mRNA for Akt, Erk1, and Erk2 in the dominant and subordinate follicles at different stages of the follicle wave. All procedures were in accordance with the Cruelty to Animals Act, 1876 (European Community Directive 86/609/EC) and licensed by the Department of Health and Children, Ireland.

In experiment 1 , differences in the Akt, Erk, JNK, and p-38 pathways in the largest two follicles from a pair of ovaries at the dominance stage of the first follicular wave were studied. Ovaries were collected at a local abattoir from four heifers at the dominance stage of the wave, as determined by the presence of a small developing corpus luteum and a group of follicles, one of which was visually larger than the other follicles (Ireland et al. 1980). After collection, ovaries were transported back to the laboratory on ice. The largest two follicles were dissected from the ovaries and measured by transillumination over a $1 \mathrm{~mm}$ grid (Evans \& Fortune 1997). Follicular fluid was aspirated, snap frozen in liquid nitrogen, and stored at $-20{ }^{\circ} \mathrm{C}$ for estradiol measurement. The follicles were then cut open; the follicle wall (granulosa and theca cells together) was peeled from the stroma and then snap frozen in liquid nitrogen, and stored at $-80{ }^{\circ} \mathrm{C}$ (Evans \& Fortune 1997).

In experiment 2, differences in the Akt, Erk, JNK, and p-38 pathways were measured in the largest two follicles at the emergence and selection stages of the first follicular wave. Eight beef heifers were synchronized using progesterone-releasing intravaginal devices (PRID, CEVA Animal Health, UK) for 10 days. Heifers were injected with a $3 \mathrm{ml}$ synthetic prostaglandin F2 $\alpha$ analog $(22.5 \mathrm{mg}$ Prostianol, Prosolvin, Intervet, Dublin, Ireland) 9 days after PRID insertion and the following day the PRID was removed. Cows were then checked for estrous behavior every $12 \mathrm{~h}$. Day 0 of the estrous cycle started when estrous behavior was first detected. Follicle development was monitored on a daily basis in each heifer from day 0 of the cycle by transrectal ultrasonography using a real-time B mode scanner with a $7.5 \mathrm{MHz}$ linear array transducer (Evans et al. 2000). Based on ultrasonographic observations, cattle were randomly assigned to be ovariectomized at two different time points: emergence of the first follicular wave (approximately day 1.5 of cycle; $n=4$ ) when all follicles were of a similar size or about the time of selection of the dominant follicle (approximately day 2.5 of the cycle; $n=4)$. All follicles $>3 \mathrm{~mm}$ were dissected from ovaries, the diameter was measured, and the largest two follicles retained. Follicular fluid was aspirated from each follicle and stored at $-20^{\circ} \mathrm{C}$. Follicles were then bisected and theca with adherent granulosa cells was peeled from the remaining stromal tissue in PBS. Granulosa cells (including the cumulus oocyte complex) were then recovered by gently scraping the cells from the theca layer using a glass scraper, and the separated cells were stored at $-80^{\circ} \mathrm{C}$ (Evans \& Fortune 1997).

In experiment 3 , the above experiment was repeated to more closely examine the emergence stage of the follicle wave. Pairs of ovaries were collected from heifers $(n=4)$ at a local abattoir at the time of emergence of the first follicular wave (days 1-2 of the cycle), as 
determined by the physical presence of a recent ovulation and many small follicles on the ovaries (Ireland et al. 1980) and similar follicular fluid estradiol concentrations. All follicles $>3 \mathrm{~mm}$ were dissected from the ovaries and measured. Follicular fluid and granulosa and theca cell samples were collected, as previously described for experiment 2 .

In experiment 4, we studied the differences in the levels of mRNA for Akt, Erk1, and Erk2 among dominant and subordinate follicles at the emergence, selection, and dominance stages of the follicular wave. Fifteen cows (Charolais $\times$ Limousine; 26-40 months of age) were synchronized, as previously described for experiment 2 . The cattle were then observed for signs of estrous behavior and follicle development was monitored by transrectal ultrasonography (Evans \& Fortune 1997). These cattle were randomly assigned to be slaughtered at three different time points; emergence of the first follicular wave (approximately day 1.5 of cycle), selection of dominant follicle (approximately day 2.5), or dominance phase of the first follicle wave (approximately day 3.5). All follicles $>3 \mathrm{~mm}$ were dissected from each pair of ovaries and measured by transillumination on a $1 \mathrm{~mm}$ grid. Follicular fluid was aspirated from the follicles and stored at $-80^{\circ} \mathrm{C}$. Individual follicles were then cut open and immersed in RNAlater (Sigma). Theca and granulosa cells were isolated as previously described and the theca layer was snap frozen in $1 \mathrm{ml}$ Trizol using liquid nitrogen. Granulosa cells were pelleted and the RNAlater was removed and replaced with $1 \mathrm{ml}$ Trizol. The cells were resuspended by vortexing and also snap frozen in liquid nitrogen. All samples were stored at $-80^{\circ} \mathrm{C}$ until RNA extraction (Evans et al. 2004).

\section{Analysis of follicular fluid}

Estradiol concentrations were measured in follicular fluid samples by RIA as previously described (Prendiville et al. 1995) using a Biodata Estradiol MAIA kit (Scintillation Proximity Assay, radioimmunoassay kit, Code 12264, Biochem Immunosystems, Bologna, Italy). The sensitivity was $0.031 \mathrm{pg} /$ tube and the inter-assay coefficients of variation (CV values) were $12.4,11.8$, and $12.8 \%$ for low, medium, and high standards respectively and the intra-assay CV values were $7.4,8.9$, and $13.2 \%$ for low, medium, and high standards respectively.

Progesterone concentrations were measured in follicular fluid samples by a single fluoroimmunoassay (AutoDELFIA Progesterone, Wallac Oy, Turku, Finland; Evans \& Martin 2000). The sensitivity of the assay was 3 pg/tube and intra-assay CV values were 5.1 and $4.6 \%$ for reference samples containing low and medium standards respectively.

The relative levels of IGFBP- 4 in follicular fluid were measured in the largest two (experiment 2) and three (experiment 3) follicles from each heifer using ligand blotting (Canty et al. 2005). Follicular fluid samples were boiled at $95{ }^{\circ} \mathrm{C}$ with a non-reducing sample buffer for $3 \mathrm{~min}$ and then resolved on a $12 \%$ SDS-polyacrylamide gel alongside a molecular weight marker (Sigma-Aldrich) at $100 \mathrm{~V}$ for $2 \mathrm{~h}$ (Bio-Rad vertical mini-gel apparatus). The proteins were then electrophoretically transferred onto an Immobilon-NC Pure membrane (Millipore, Cork, Ireland) at $40 \mathrm{~V}$ and at $4{ }^{\circ} \mathrm{C}$ overnight. After transfer was complete (as confirmed by visual assessment of transfer of molecular weight markers), membranes were washed in PBS (pH 7.4) with 0.1\% IGEPAL (CA-40, Sigma-Aldrich Ireland Ltd) for $10 \mathrm{~min}$ and subsequently blocked in $0.5 \%$ gelatine in PBS for $4 \mathrm{~h}$. There was a further wash in PBS with $0.1 \%$ Tween 20 for 10 min before the membrane was incubated at $4{ }^{\circ} \mathrm{C}$ overnight with ${ }^{125} \mathrm{I}$-rhIGF-II (R\&D Systems Europe, Abingdon, UK, $1.8 \times 10^{6}$ c.p.m. $/ 150 \mu \mathrm{l}$, $25 \mathrm{ml}$ ). The IGF-II was iodinated using a modification of the chloramine-T method (Greenwood et al., 1963, Spicer et al, 1981). The modified method consisted of incubating $2 \mu \mathrm{g}$ IGF-II with $0.5 \mathrm{mCi} \mathrm{Na}\left[{ }^{125} \mathrm{I}\right]$ and $1.60 \mu \mathrm{g}$ chloramine-T for $20 \mathrm{~s}$ at room temperature. Addition of $6 \mu \mathrm{g}$ sodium metabisulfate stopped the reaction and ${ }^{125}$ I-IGF-II was purified from the reaction mixture using Sephadex G-25 gel chromatography (Sigma-Aldrich Ireland Ltd) with a $1 \mathrm{M}$ acetic acid/BSA elution buffer. Following the overnight incubation, membranes were washed for a final time in PBS-Tween for $4-5 \mathrm{~h}$ and then air-dried. When dry, the membranes were wrapped in a plastic wrap and exposed to X-ray film at $-80^{\circ} \mathrm{C}$ overnight.

\section{Immunoblotting}

Tissue samples were thawed on ice and then homogenized in $200 \mu \mathrm{l}$ cold extraction buffer $(10 \mathrm{mM}$ Hepes $\mathrm{pH}$ 7.9, $1 \mathrm{mM}$ EDTA, $0.5 \mathrm{M}$ dithiothreitol, $10 \%$ glycerol, $400 \mathrm{mM} \mathrm{KCl}, 5 \mu \mathrm{g} / \mathrm{ml}$ pepstatin, $5 \mu \mathrm{g} / \mathrm{ml}$ aprotinin, $5 \mathrm{mM}$ benzamidine; Eul et al. 1989). The homogenate was then centrifuged at 14000 r.p.m. (Eppendorf centrifuge) for $5 \mathrm{~min}$ at $4{ }^{\circ} \mathrm{C}$. The resulting supernatant was retained, snap frozen in liquid nitrogen, and stored at $-80{ }^{\circ} \mathrm{C}$. Protein concentrations of the sample extracts were determined by spectrophotometric assay using the Bio-Rad estimate concentrate.

The levels of Akt, Erk, JNK, and p-38 and their phosphorylated forms were measured in the granulosa and theca cells using western blot analysis (Evans \& Martin 2000). Samples tested for each animal were run on a single gel for each protein of interest (negating gelto-gel effects when comparing protein levels among follicles within animals). Separate gels were run for each of the proteins being measured. Granulosa and theca cell extracts were resolved on $10 \%$ SDS-polyacrylamide gels ( $20 \mu \mathrm{g}$ total protein per lane) and then electrophoretically transferred onto nitrocellulose (Protran, Whatman Schleicher \& Schuell Bioscience, Lennox Laboratory Supplies Ltd, Dublin 12, Ireland), using the Bio-Rad Wet Blot Transfer Cell apparatus with approximately 3 I transfer buffer (20 mM Tris base, $0.15 \mathrm{M}$ glycine, 1\% 
SDS, $20 \%$ methanol). Transfer was performed at $200 \mathrm{~V}$ for $1.5 \mathrm{~h}$ at $4{ }^{\circ} \mathrm{C}$. After transfer, the membranes were stained with Ponceau S stain solution (Sigma-Aldrich Ireland Ltd) to validate equal loading and transfer of protein among samples. After destaining with TBS-Tween (Tris-buffered saline with Tween 20, $25 \mathrm{nM}$ Tris base, $0.15 \mathrm{M} \mathrm{NaCl}, 0.05 \%$ Tween 20, pH 7.6), the membrane was blocked in 5\% non-fat dried milk (SigmaAldrich) in TBS-Tween for 1-2 $\mathrm{h}$. The blocking solution was then removed and the membrane incubated/rotated overnight (14-16 h) in a $50 \mathrm{ml}$ polypropylene centrifuge tube (210270, Greiner Bio-One, Glouchester, UK), with the appropriate antibody diluted in 5\% BSA in TBS-Tween at $4{ }^{\circ} \mathrm{C}$. The following antibodies (all rabbit polyclonal antibodies supplied by New England Biolabs (UK) Ltd, Hitchin, UK) were used: anti-Akt (\#9272, 1:2000), anti-phospho-Akt (\#9271, 1:1000), anti-Erk (\#9102, 1:2000), anti-phospho-Erk (\#9101，1:1000), anti-JNK (\#9252, 1:888), anti-phospho-JNK (\#9251, 1:888), anti-p-38 (\#9212, 1:1000), and anti-phospho-p38 (\#9211, 1:1000). After incubation with the primary antibody, the membrane was washed twice for $10 \mathrm{~min}$ in TBS-Tween and then incubated for a further $2 \mathrm{~h}$ at room temperature, with a polyclonal goat anti-rabbit $(1: 10000) \quad$ IgG-HRP-conjugated immunoglobulin (Dako, Cambridge, UK) diluted in 5\% Marvel in TBS-Tween. The secondary antibody was removed and the blot was washed five times for $7 \mathrm{~min}$ in TBS-Tween. Protein bands were detected using ECL (Supersignal West Femto Max Sensitivity Substrate, Pierce; Medical Supply Company, Dublin, Ireland), according to manufacturer's instructions and autoradiography.

\section{Image analysis}

The relative intensity of the protein bands representing Akt, phospho-Akt, Erk, phospho-Erk, p-38, phospho-p38, JNK, phospho-JNK, and IGFBP-4 was measured using Scion Image software (http://www.scioncorp. com). Autoradiographic images of the blots were scanned and saved in tagged image file format (.tiff) in an uncompressed format to permit analysis. The band of interest was selected and the mean pixel intensity determined $(0=$ white, no intensity; $256=$ black, maximum intensity). Background intensity, measured as the intensity of area adjacent to the selected band, was subtracted from individual values.

\section{Quantitative real-time PCR}

Granulosa and theca samples were rapidly thawed at $37^{\circ} \mathrm{C}$ and total RNA was extracted using Trizol reagent, according to manufacturer's instructions and as previously described (Evans et al. 2004). Total RNAs were quantified by measuring the absorbance at $260 \mathrm{~nm}$ (Beckman Coulter DU 530 Lifescience u.v.-vis spectrometer). Following DNase treatment, which was carried out using RQ1 DNase (Promega) following manufacturer's instructions, cDNA was synthesized according to the Invitrogen Superscript First-strand cDNA synthesis protocol.

Quantitative real-time PCR was performed using the MX3000 Real-Time PCR instrument and was used to determine differences in mRNA expression levels for Akt, Erk1, and Erk2 between the dominant and the two largest subordinate follicles within different stages of the first follicular wave. In brief, each $25 \mu \mathrm{l}$ reaction mixture consisted of $12.5 \mu \mathrm{l} 2 \times$ Stratagene Brilliant SYBR Green PCR Master Mix (which includes buffer, DNA polymerase, dNTPs, SYBR Green; Stratagene, Cedar Creek, Texas, USA), $1.5 \mu \mathrm{l}$ forward/reverse primer mix at $900 \mathrm{nM} / 900 \mathrm{nM}$, $9 \mu \mathrm{l}$ nuclease-free water, and $2 \mu \mathrm{l}$ cDNA template that corresponded to $20 \mathrm{ng}$ cDNA. The cycling thermal profile used to amplify the target cDNA sequences involved $50{ }^{\circ} \mathrm{C}$ for $2 \min \left(1\right.$ cycle), $95^{\circ} \mathrm{C}$ for $10 \mathrm{~min}$ ( 1 cycle), $95{ }^{\circ} \mathrm{C}$ for $15 \mathrm{~s}$, and $60^{\circ} \mathrm{C}$ for $1 \mathrm{~min}$ (50 cycles), and the dissociation curve involved $95^{\circ} \mathrm{C}$ for $1 \mathrm{~min}$ (1 cycle) and $55^{\circ} \mathrm{C}$ back up to $95^{\circ} \mathrm{C}\left(0.5^{\circ} \mathrm{C} / \mathrm{s}\right.$ for $30 \mathrm{~s}=81$ cycles $)$. Primer sequences were designed using the 'Primer Express' software package and are shown in Table 1. Each template was analyzed in duplicate and controls, with no template, were run within each plate to test for contamination. The expression level of each target gene was normalized against the levels of the constitutive housekeeping gene $\beta$-actin (Evans et al. 2004).

Relative expression of Akt, Erk1, and Erk2 mRNA was determined using the comparative threshold cycle (Ct). In brief, the expression levels of the target genes were measured relative to the expression of $\beta$-actin and established by dividing the expression value of the target genes by the expression value of $\beta$-actin.

\section{Follicle assessment}

Based on follicle diameters and follicular fluid estradiol concentrations, follicles collected at the selection and dominance stages of the follicular wave were easily identified as being dominant or subordinate (experiments 1 and 2). However, by definition, there are no differences in follicle diameter or follicular fluid estradiol concentrations among follicles collected at follicle wave emergence. Therefore, follicles at this stage were assigned within animals as the putative dominant follicle or the putative

Table 1 Primer sequences for Akt, Erk1, Erk2, and $\beta$-actin were designed using 'Primer Express' software.

\begin{tabular}{lll}
\hline Gene & Forward sequence & Reverse sequence \\
\hline Akt & GAGTACTTCAGGGCCGTAG & GGTGATCCTGGTGAAGGAGA \\
Erk1 & AATGCAGCCCACAGACCAGAT & CACACTGGCTTTCTGACGGAA \\
Erk2 & GAAGACGCAACACCTCAGCAA & TGGAAGGTTTGAGGTCACGGT \\
$\beta$ - Actin & CGCCATGGATGATGATATTGC & AAGCCGGCCTTGCACAT \\
\hline
\end{tabular}


first or second subordinate follicles based on the relative levels of Akt and Erk proteins present in the theca and granulosa cells (experiments 2 and 3), and corresponding to the pattern of protein expression in the (later) selection and dominance stages of the follicle wave (experiments 1 and 2). This approach was deemed valuable, as it indicated that the levels of multiple signaling proteins were highest in one follicle within each animal (an approach that would not have been satisfactory if attempting to demonstrate differences in only one protein).

In experiment 4, animals were assigned to groups (different stages of the wave) based on follicle diameters and follicular fluid estradiol concentrations. When there was a clear dominant follicle present, which had the greatest diameter and follicular fluid estradiol concentrations that were at least twice as high as the next largest follicle, animals were classed as belonging to the dominance group $(n=7)$. Animals were assigned to the selection group $(n=4)$ when the largest follicle (considered as the dominant follicle) had estradiol concentrations that were between 1.5 and 2 times greater than the next largest follicle (Evans \& Fortune 1997, Austin et al. 2001). When diameter differences and follicular fluid estradiol differences among follicles were small, animals were assigned to the emergence group $(n=4)$ and follicles were ranked based on follicular fluid estradiol concentrations. Only the three most 'senior' follicles from each animal were included in the gene expression analyses.

\section{Statistical analysis}

Differences among follicles at the different stages of the wave were compared by ANOVA using the general linear model procedures of SAS and subsequent multiple comparisons among follicle types were made using Tukey's honestly significant difference. The animal was included in the statistical model to negate the large animal-to-animal variation. All values are given as the mean \pm s.E.M.

\section{Results}

\section{Experiment 1: signaling proteins at the dominance stage}

There was a clear dominant follicle present, which was larger $(P=0.001)$ and had a higher follicular fluid estradiol concentration $(P=0.044)$ than the largest subordinate follicle (Table 2). The mean corpus luteum diameter was $14.0 \pm 2.5 \mathrm{~mm}$. Dominant follicles also had higher levels of Akt $(P=0.048)$, Erk $(P=0.017)$, JNK $(P=0.038)$, and p-38 $(P=0.046)$, and also higher levels of phospho-Akt $(P=0.032)$ and phospho-Erk $(P=0.024)$ than the largest subordinate follicle (Table 2). Levels of phospho-JNK and phospho-p-38 were barely detectable (data not shown).
Table 2 Mean ( \pm S.E.M.) follicle diameter, follicular fluid (FF) estradiol concentration, and levels of signal transduction proteins in the follicle wall of the dominant and largest subordinate follicle from ovaries collected at an abattoir at the dominance stage of the follicle wave ( $n=4$ heifers).

\begin{tabular}{lccc}
\hline & Dominant & Subordinate & Significance \\
\hline Diameter $(\mathrm{mm})$ & $8.9 \pm 0.4$ & $7.0 \pm 0.4$ & 0.001 \\
FF estradiol $(\mathrm{ng} / \mathrm{ml})$ & $161.2 \pm 60.7$ & $78.1 \pm 42.0$ & 0.044 \\
Follicle wall & & & \\
$\quad$ Akt & $158 \pm 21$ & $62 \pm 33$ & 0.048 \\
p-Akt & $101 \pm 26$ & $30 \pm 11$ & 0.032 \\
Erk & $79 \pm 17$ & $15 \pm 13$ & 0.017 \\
p-Erk & $125 \pm 5$ & $32 \pm 19$ & 0.024 \\
JNK & $135 \pm 30$ & $32 \pm 19$ & 0.038 \\
p-38 & $101 \pm 15$ & $42 \pm 12$ & 0.046 \\
\hline
\end{tabular}

Protein levels measured in arbitrary units 1-256.

\section{Experiments 2 and 3: signaling proteins at selection and emergence stages}

In the selected group of follicles, the dominant follicle had a greater diameter $(P=0.045)$ and higher follicular fluid estradiol concentration $(P=0.034)$ than the largest subordinate follicle (Table 3). Furthermore, levels of IGFBP-4 were lower $(P=0.03)$ in the dominant follicle than the largest subordinate follicle (Table 3). There were no differences in progesterone concentrations between dominant and subordinate follicles $(P>0.05)$. Levels of Akt $(P=0.043)$ and p-Akt $(P=0.047)$ were higher in the granulosa cells and p-Akt $(P=0.023)$ in the theca cells of dominant compared with the largest subordinate follicle with higher levels of p-Erk $(P=0.061)$ and p-38

Table 3 Mean ( \pm s.E.M.) follicle diameter, follicular fluid (FF) estradiol and progesterone concentrations, follicular fluid IGFBP-4 levels, and levels of signal transduction proteins in the granulosa and theca cells of the dominant and largest subordinate follicle from heifers $(n=4)$ ovariectomized about the time of dominant follicle selection (day 2.5).

\begin{tabular}{lccc}
\hline & Dominant & Subordinate & Significance \\
\hline Diameter & $8.3 \pm 0.5$ & $7.0 \pm 0.5$ & 0.045 \\
FF estradiol & $121.1 \pm 49.0$ & $29.2 \pm 22.1$ & 0.034 \\
FF progesterone & $11.4 \pm 3.0$ & $5.3 \pm 1.6$ & $\mathrm{NS}$ \\
FF IGFBP-4 & $1.04 \pm 0.79$ & $9.04 \pm 4.15$ & 0.030 \\
Granulosa cell & & & \\
Akt & $91 \pm 7$ & $73 \pm 13$ & 0.043 \\
p-Akt & $74 \pm 26$ & $57 \pm 29$ & 0.047 \\
Erk & $95 \pm 5$ & $98 \pm 1$ & $\mathrm{NS}$ \\
p-Erk & $120 \pm 6$ & $109 \pm 15$ & $\mathrm{NS}$ \\
JNK & $48 \pm 5$ & $55 \pm 8$ & $\mathrm{NS}$ \\
p-JNK & $103 \pm 13$ & $68 \pm 26$ & $\mathrm{NS}$ \\
p-38 & $53 \pm 8$ & $60 \pm 17$ & $\mathrm{NA}$ \\
Theca cell & $55 \pm 13$ & $47 \pm 17$ & $\mathrm{NS}$ \\
Akt & $93 \pm 15$ & $34 \pm 6$ & 0.023 \\
p-Akt & $66 \pm 8$ & $71 \pm 4$ & $\mathrm{NS}$ \\
Erk & $149 \pm 5$ & $79 \pm 34$ & 0.061 \\
p-Erk & $76 \pm 4$ & $74 \pm 19$ & $\mathrm{NS}$ \\
JNK & $154 \pm 25$ & $88 \pm 46$ & $\mathrm{NS}$ \\
p-JNK & $101 \pm 15$ & $79 \pm 23$ & 0.069 \\
p-38 & & \\
\hline
\end{tabular}

NS, not significant; NA, not applicable; protein levels measured in arbitrary units 1-256. 
$(P=0.069)$ in the theca tending towards significance (Table 3).

Data for individual follicles from the emergence group in experiment 2 are shown in Table 4. A higher level of Akt and p-Akt in the granulosa cells and p-Akt and p-Erk in the theca cells was chosen as the criterion for assigning putative status of follicles in the emergence group. This was based on our earlier findings that showed that at the selection stage of the wave, there were higher levels of Akt and p-Akt in the granulosa cells and higher levels of p-Akt and p-Erk in the theca cells of dominant compared with subordinate follicles. In addition, there were higher levels of Akt, p-Akt, Erk, and $p$-Erk in the follicle wall of dominant follicles compared with subordinate follicles at the dominance stage of the wave. Follicle diameter and follicular fluid estradiol and progesterone concentrations were low and did not differ between the putative dominant and largest subordinate follicles $(P>0.05$; Table 5$)$. Levels of Akt and p-Akt were higher in the granulosa cells $(P=0.013$ and 0.019 respectively) and $p$-Erk in the theca cells $(P=0.041)$ of the putative dominant compared with the putative subordinate follicle (Table 5). Levels of p-Akt were higher in the theca cells of putative dominant follicle than the putative subordinate follicle in three of the four animals (Table 4), but the two groups were not different $(P=0.10$; Table 5).

Data for individual follicles in experiment 3 are shown in Table 6 and representative immunoblots in Fig. 1. As previously described, the putative follicle status was based on the levels of Akt and p-Akt in the granulosa cells and p-Akt and p-Erk in the theca cells. The mean follicular fluid estradiol concentrations and IGFBP-4 levels were low and similar $(P>0.05)$ among the putative follicle types (Table 7). The diameters of the putative dominant follicle, the putative largest subordinate follicle, and the putative second largest follicle were similar ( $P>0.05$; Table 7). When follicle groups were compared, the putative dominant follicle had higher levels of $\mathrm{p}$-Akt $(P=0.001)$ and $\mathrm{p}$-Erk $(P=0.050)$ in the granulosa cells and higher levels of p-Akt $(P=0.019)$ and p-Erk $(P=0.007)$ in the theca cells, compared with both the putative subordinate follicles (Table 7). Akt was also higher $(P<0.05)$ in the granulosa cells of the putative dominant follicle than the putative second largest subordinate follicle (Table 7).

\section{Experiment 4: Akt, Erk1, and Erk2 mRNA expression}

In the emergence group, there were no differences among the follicle groups in follicular fluid estradiol concentrations $(12.9 \pm 1.0$ vs $9.4 \pm 1.4$ vs $9.4 \pm 2.0 \mathrm{ng} / \mathrm{ml}$; $P>0.5)$, but there was a difference $(P<0.05)$ in the diameters of the putative dominant and the putative second largest subordinate follicle, with the largest subordinate follicle intermediate between the two $(6.9 \pm 0.4$ vs $6.4 \pm 0.6$ vs $6.0 \pm 0.2 \mathrm{~mm})$. At the selection stage of the follicle wave, follicular fluid estradiol concentration in the dominant follicle was higher $(P<0.05)$ than both the subordinate follicles $(15.1 \pm 6.7$ vs $8.8 \pm 3.4$ vs $5.7 \pm 1.9 \mathrm{ng} / \mathrm{ml})$. However, there were no differences $(P>0.05)$ between the largest and second largest subordinate follicles. The dominant follicle was also larger $(P<0.05)$ than both the subordinate follicles with no differences $(P>0.05)$ between subordinates $(7.0 \pm 0.6$ vs $5.9 \pm 0.7$ vs $5.6 \pm 0.4 \mathrm{~mm})$. By the dominance stage of the follicular wave, there was a clear hierarchy established. The dominant follicle had the highest follicular fluid estradiol concentration, which was higher $(P<0.05)$ than the concentration in the largest subordinate, which, in turn, was higher $(P<0.05)$ than the concentration in the second largest subordinate (288.6 \pm 126.0 vs $89.2 \pm 82.3$ vs $3.7 \pm 2.6 \mathrm{ng} / \mathrm{ml}$ ). Changes in follicle diameter followed a similar pattern with the

Table 4 Individual characteristics of the two largest follicles from heifers $(n=4)$ ovariectomized about the time of emergence (day 1.5$)$. The follicle number was assigned to individual follicles at the time of dissection for identification purposes.

\begin{tabular}{|c|c|c|c|c|c|c|c|c|}
\hline \multirow{3}{*}{$\begin{array}{l}\text { Animal } \\
\text { Follicle number } \\
\text { Putative status }\end{array}$} & \multicolumn{2}{|c|}{41} & \multicolumn{2}{|c|}{47} & \multicolumn{2}{|c|}{48} & \multicolumn{2}{|c|}{62} \\
\hline & 5 & 4 & 1 & 4 & 1 & 2 & 2 & 1 \\
\hline & $\mathrm{D}$ & S1 & $\mathrm{D}$ & S1 & $\mathrm{D}$ & S1 & $\mathrm{D}$ & S1 \\
\hline Diameter (mm) & 4.0 & 4.5 & 5.5 & 4.5 & 5.0 & 5.0 & 7.0 & 7.0 \\
\hline FF estradiol (ng/ml) & 10.5 & 8.8 & 11.2 & 5.2 & 16.9 & 16.2 & 9.3 & 9.7 \\
\hline FF progesterone (ng/ml) & 0.8 & 0.2 & 5.1 & 1.3 & 1.7 & 4.5 & 2.3 & 8.6 \\
\hline FF IGFBP-4 & 0 & 9.43 & 2.26 & 7.76 & 0.05 & 0 & 6.83 & 3.42 \\
\hline \multicolumn{9}{|l|}{ Granulosa } \\
\hline Akt & 5 & 1 & 45 & 28 & 47 & 33 & 114 & 103 \\
\hline p-Akt & 11 & 9 & 40 & 22 & 59 & 23 & 11 & 7 \\
\hline Erk & 11 & 20 & 78 & 105 & 79 & 77 & 42 & 78 \\
\hline p-Erk & 43 & 48 & 144 & 65 & 54 & 66 & 152 & 1 \\
\hline \multicolumn{9}{|l|}{ Theca } \\
\hline Akt & 136 & 32 & 185 & 120 & 114 & 109 & 131 & 176 \\
\hline p-Akt & 34 & 3 & 185 & 84 & 65 & 42 & 60 & 66 \\
\hline Erk & 173 & 140 & 29 & 1 & 82 & 1 & 1 & 1 \\
\hline p-Erk & 52 & 13 & 20 & 9 & 9 & 6 & 20 & 17 \\
\hline
\end{tabular}

Protein levels measured in arbitrary units 1-256. Protein levels in boldface indicate the follicle with the highest level within an animal. 
Table 5 Mean ( \pm s.E.M.) follicle diameter, follicular fluid (FF) estradiol and progesterone concentrations, follicular fluid IGFBP-4 levels, and levels of Akt, p-Akt, Erk, and p-Erk in the granulosa and theca cells of the dominant and largest subordinate follicle.

\begin{tabular}{lccc}
\hline & $\begin{array}{c}\text { Putative } \\
\text { dominant }\end{array}$ & $\begin{array}{c}\text { Putative } \\
\text { subordinate }\end{array}$ & Significance \\
\hline Diameter $(\mathrm{mm})$ & $5.4 \pm 0.6$ & $5.3 \pm 0.6$ & $\mathrm{NS}$ \\
FF estradiol $(\mathrm{ng} / \mathrm{ml})$ & $12.0 \pm 1.7$ & $10.0 \pm 2.3$ & $\mathrm{NS}$ \\
FF progesterone $(\mathrm{ng} / \mathrm{ml})$ & $2.5 \pm 0.9$ & $3.7 \pm 1.9$ & $\mathrm{NS}$ \\
FF IGFBP-4 & $2.29 \pm 1.60$ & $5.15 \pm 2.13$ & $\mathrm{NS}$ \\
Granulosa cell & & & \\
$\quad$ Akt & $53 \pm 23$ & $41 \pm 22$ & 0.013 \\
p-Akt & $30 \pm 12$ & $15 \pm 4$ & 0.019 \\
Erk & $53 \pm 17$ & $69 \pm 18$ & $\mathrm{NS}$ \\
p-Erk & $98 \pm 29$ & $45 \pm 15$ & $\mathrm{NS}$ \\
Theca cell & $142 \pm 15$ & $110 \pm 13$ & $\mathrm{NS}$ \\
$\quad$ Akt & $86 \pm 33$ & $49 \pm 18$ & 0.10 \\
p-Akt & $71 \pm 38$ & $36 \pm 35$ & $\mathrm{NS}$ \\
Erk & $25 \pm 9$ & $11 \pm 2$ & 0.041 \\
p-Erk & & \\
\hline
\end{tabular}

Ovaries were collected from heifers $(n=4)$ ovariectomized about the time of emergence (day 1.5). NS, not significant; protein levels measured in arbitrary units 1-256.

dominant follicle larger $(P<0.05)$ than the largest subordinate, which, in turn, was larger $(P<0.05)$ than the second largest subordinate follicle $(9.6 \pm 1.6$ vs $7.6 \pm$ 1.1 vs $6.2 \pm 0.5 \mathrm{~mm}$ ). There was also a significant increase $(P<0.05)$ in the mean diameters of all the follicles from the emergence and selection stages to the dominance stage, reflecting the follicular growth through the wave.

At all stages of the follicle wave, mRNA for the three genes of interest and $\beta$-actin was detected. Mean expression levels ranged from 0.5 to 0.72 relative to $\beta$-actin in the granulosa cells, and 0.07 to 0.98 relative to $\beta$-actin in the theca cells. But there were no differences $(P>0.05)$ found among follicle types within or among each stage of the wave in the theca or granulosa cells.

\section{Discussion}

We conclude that the Erk and Akt signal transduction pathways are important for dominant follicle selection and development and, furthermore, that the observed differences in these pathways mark the future dominant follicle from subordinate follicles before other markers of dominant follicle selection (follicle diameter, follicular fluid estradiol, and IGFBP-4 concentrations) become apparent. These findings are consistent with our previous study in sheep, where a higher level of Akt, p-Akt, Erk, and $p$-Erk in the follicle wall of dominant follicles was also demonstrated (Evans \& Martin 2000). In addition, at the emergence stage of the follicle wave (before morphological selection of the dominant follicle, defined by the differences in diameter and follicular fluid estradiol, and IGFBP-4 concentrations), it was possible to identify a putative dominant follicle based on one follicle having consistently higher levels of Akt and p-Akt in the granulosa cells and p-Akt and p-Erk in the theca cells (in seven out of eight animals, p-Akt in the theca cells was also higher in the putative dominant follicle than in the other putative subordinate follicles). This pattern of protein expression was consistent with the pattern at later stages of follicle development when dominant follicles were clearly present.

Higher levels of Akt and Erk may confer a developmental advantage on the future dominant follicles by promoting survival of dominant follicle at the time when circulating FSH concentrations decline and by regulating key processes within the follicle, for example, follicle growth and estradiol production. Granulosa cell proliferation is a critical step in follicle development and both Akt and Erk pathways have been implicated in promoting cell proliferation and survival. Inhibition of the Erk pathway using specific MAPK inhibitor (PD98059) attenuated FSH-stimulated cell survival in

Table 6 Individual characteristics of the three largest follicles collected from heifers $(n=4)$ at an abattoir about the time of emergence of the first follicle wave.

\begin{tabular}{|c|c|c|c|c|c|c|c|c|c|c|c|c|}
\hline \multirow{3}{*}{$\begin{array}{l}\text { Animal } \\
\text { Follicle number } \\
\text { Putative status }\end{array}$} & \multicolumn{3}{|c|}{ A } & \multicolumn{3}{|c|}{ B } & \multicolumn{3}{|c|}{ C } & \multicolumn{3}{|c|}{ D } \\
\hline & 11 & 12 & 13 & 16 & 17 & 19 & 51 & 52 & 53 & 65 & 67 & 68 \\
\hline & $\mathrm{D}$ & S1 & S2 & $\mathrm{D}$ & S1 & S2 & $\mathrm{D}$ & S2 & S1 & $\mathrm{D}$ & S1 & S2 \\
\hline Diameter (mm) & 5.0 & 5.0 & 5.0 & 8.0 & 8.0 & 7.0 & 5.5 & 5.0 & 5.0 & 7.0 & 6.0 & 6.0 \\
\hline FF estradiol (ng/ml) & 0.7 & 2.4 & 1.9 & 41.1 & 35.6 & 47.5 & 3.7 & 2.8 & 3.6 & 18.8 & 2.0 & 21.2 \\
\hline FF IGFBP-4 & 1.3 & 0.8 & 1.2 & 0.9 & 0.7 & 0.8 & 0.6 & 0.5 & 0.8 & 1.7 & 3.7 & 2.4 \\
\hline \multicolumn{13}{|l|}{ Granulosa } \\
\hline Akt & 109 & 102 & 78 & 83 & 76 & 73 & 52 & 29 & 33 & 85 & 70 & 47 \\
\hline p-Akt & 57 & 21 & 21 & 39 & 29 & 15 & 50 & 20 & 15 & 50 & 40 & 18 \\
\hline Erk & 55 & 63 & 87 & 73 & 36 & 22 & 45 & 19 & 26 & 147 & 130 & 157 \\
\hline p-Erk & 205 & 55 & 89 & 27 & 0 & 4 & 97 & 26 & 81 & 170 & 18 & 95 \\
\hline \multicolumn{13}{|l|}{ Theca } \\
\hline Akt & 96 & 104 & 134 & 75 & 69 & 82 & 81 & 91 & 66 & 118 & 122 & 119 \\
\hline p-Akt & 78 & 42 & 57 & 32 & 24 & 12 & 77 & 63 & 32 & 107 & 64 & 61 \\
\hline Erk & 107 & 89 & 119 & 102 & 148 & 124 & 47 & 25 & 23 & 130 & 112 & 129 \\
\hline p-Erk & 116 & 84 & 86 & 34 & 8 & 0 & 87 & 42 & 51 & 89 & 68 & 73 \\
\hline
\end{tabular}

The follicle number was assigned to individual follicles at the time of dissection for identification purposes. Protein levels measured in arbitrary units 1-256. Protein levels in boldface indicate the follicle with the highest level within an animal. 


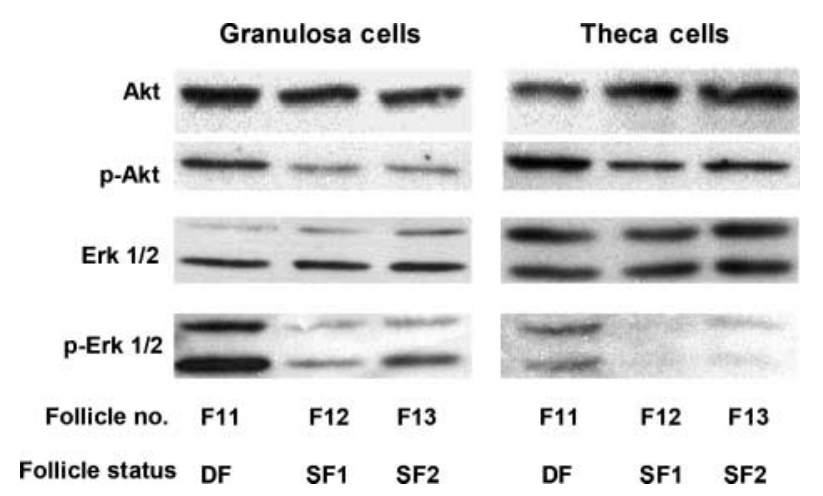

Figure 1 Representative western immunoblots showing levels of Akt, p-Akt, Erk and p-Erk in the three largest follicles collected from a heifer at an abattoir about the time of emergence of the first follicle wave.

porcine granulosa cells in vitro, by increasing the activity of pro-apoptotic Bad protein (Shiota et al. 2003). Furthermore, inhibition of Erk in rat granulosa cells in vitro reduced the expression of cyclin D2, which is involved in cell cycle progression (Kayampilly \& Menon 2004). Other research has shown that IGF-I-mediated cell survival was reduced by the inhibition of the Akt pathway with a specific PI3-kinase inhibitor (LY294002) in bovine granulosa cells (Hu et al. 2004). Although it is generally thought that FSH acts through the Erk pathway to promote growth and differentiation and IGF through the Akt pathway to support growth and survival, the picture is not so clear. Both FSH and IGF-I activate multiple signaling pathways. FSH has been shown to activate both Akt (Gonzalez-Robayna et al. 2000) and Erk (Das et al. 1996) pathways in addition to PKA (Conti 2002). Moreover, IGF-I has also been shown to activate Akt and Erk (Hu et al. 2004) in addition to enhancing the effects of FSH on granulosa cells (Minegishi et al. 2000).

Table 7 Mean ( \pm S.E.M.) follicle diameter, follicular fluid estradiol concentrations, follicular fluid IGFBP-4 levels, and levels of Akt, p-Akt, Erk, and p-Erk in the granulosa and theca cells of the dominant and largest two subordinate follicles from heifers $(n=4)$ about the time of emergence of the first follicle wave.

\begin{tabular}{lcccc}
\hline & \multicolumn{4}{c}{ Putative follicle status } \\
\cline { 2 - 5 } & Dom & SF1 & SF2 & Significance \\
\hline Diameter (mm) & $6.4 \pm 0.7$ & $6.0 \pm 0.7$ & $5.8 \pm 0.5$ & NS \\
FF estradiol (ng/ml) & $16.1 \pm 9.2$ & $10.9 \pm 8.2$ & $18.4 \pm 10.7$ & NS \\
FF IGFBP-4 & $1.1 \pm 0.3$ & $1.5 \pm 0.7$ & $1.2 \pm 0.4$ & NS \\
Granulosa & & & & \\
$\quad$ Akt & $82 \pm 12^{*}$ & $70 \pm 14^{*}$ & $57 \pm 11^{+}$ & 0.017 \\
p-Akt & $49 \pm 4^{*}$ & $26 \pm 5^{+}$ & $19 \pm 1^{+}$ & 0.001 \\
Erk & $80 \pm 23$ & $64 \pm 23$ & $71 \pm 33$ & NS \\
p-Erk & $125 \pm 40^{*}$ & $39 \pm 18^{+}$ & $54 \pm 23^{+}$ & 0.050 \\
Theca & & & & \\
$\quad$ Akt & $93 \pm 10$ & $90 \pm 14$ & $107 \pm 12$ & NS \\
p-Akt & $74 \pm 15^{*}$ & $41 \pm 9^{+}$ & $48 \pm 12^{+}$ & 0.019 \\
$\quad$ Erk & $97 \pm 18$ & $93 \pm 26$ & $100 \pm 25$ & NS \\
p-Erk & $82 \pm 17^{*}$ & $53 \pm 16^{+}$ & $50 \pm 19^{+}$ & 0.007 \\
\end{tabular}

NS, not significant; protein levels measured in arbitrary units 1-256. $*^{+}<0.05$.
Therefore, it is reasonable to suggest that there is potential for crosstalk between FSH and IGF-I signaling through the Akt and Erk pathways, and that these pathways are critical for the successful development of dominant follicles from the very earliest stages of development.

Previous work demonstrated JNK and p-38 activity in rat granulosa cells (Gebauer 1999) and a limited role for JNK signaling in apoptosis was suggested (Peter \& Dhanasekaran 2003). In the present experiment, there were differences in the levels of JNK and p-38 at the dominance stage of the follicle wave (Table 2), but these differences were small and not significant at the selection phase of the follicle wave (Table 3). We therefore suggest that loss of JNK and p-38 signaling pathways is involved in the later stages of subordinate follicle regression, but that these pathways do not mediate intracellular signaling that regulates dominant from subordinate follicle selection.

Throughout the follicle wave, at all three time points (i.e., emergence, selection, and dominance), there were consistent differences in the levels of total Akt and p-Akt in the granulosa cells and the degenerative changes that are associated with follicular atresia appear initially in the granulosa layer (Yang \& Rajamahendran 2000). At the dominance stage, differences in the levels of total Erk and p-Erk were also observed in the follicle wall. To determine whether these protein differences were due to regulation at the gene expression levels, levels of Akt, Erk1, and Erk2 mRNA were measured, but there were no differences among follicle types at any stage of the follicle wave (experiment 4). This suggests that the differences are due to either a disruption of protein production or processing (e.g. altered mRNA stability and/or impaired translation) or to an increase in degradation of the signaling proteins associated initially with follicle selection and later with subordinate follicle regression.

The biological mechanism by which a species-specific number of dominant follicles in mammals are selected from a morphologically equivalent cohort of follicles, while the remaining follicles of the cohort regress, is not known. Subordinate and dominant follicles develop in the same endocrine environment, but it is likely that the selection process involves the differential expression of factors that mediate the actions of FSH and IGF-I. The present results show the differences in the Akt and Erk pathways among follicle types at critical stages of the follicle wave and before the other markers of follicle differentiation that were assessed in this study. However, the exact nature of the relationship (if any) between the Akt and Erk pathways and recognized markers of follicle differentiation (e.g. changes in the IGFBP-2, -4 , and -5 and IGFPB proteases, e.g. PAPP-A) remains to be determined and requires further work. We suggest that the Akt and Erk pathways may mediate the actions of key follicle-regulating hormones and that they may be targets 
against which substances can be developed to regulate follicle development. In addition, further investigation into the downstream targets of the Akt and Erk pathways (e.g. phospho-Bad and cyclin D2) may yield additional and potentially more reliable markers of follicle development and selection.

In summary, differences in the Akt, Erk, JNK, and p-38 signaling pathways between follicle types were clear at the dominance stage of the follicle wave, but only differences in the Akt and Erk pathways were observed among dominant and subordinate follicles earlier in the follicle wave, immediately after dominant follicle selection. Based on this similar relationship among follicles of Akt and Erk proteins in selected follicles, we suggest that we have identified the putative future dominant and putative future subordinate follicles from the pool of otherwise similar cohort follicles at the time of follicle wave emergence. We conclude that the Erk and Akt signal transduction pathways are important for dominant follicle development and, furthermore, that the observed differences in these pathways indicate the future dominant follicle from subordinate follicles before other markers of dominant follicle selection (follicle diameter, follicular fluid estradiol, and IGFBP-4 concentrations) become apparent.

\section{Acknowledgements}

We thank P Duffy and MP Boland for their assistance with the animals; $\mathrm{N}$ Hynes for carrying out the radioimmunoassays. This work was funded by a UCD President's Research Award, an Enterprise Ireland Basic Research grant (SC/2001/0410), and a Science Foundation Ireland grant (02/IN1/B78). The authors declare that there is no conflict of interest that would prejudice the impartiality of this scientific work.

\section{References}

Adams GP, Matteri RL, Katelic JP, Ko JCH \& Ginther OJ 1992 Association between surges of follicle-stimulating hormone and the emergence of follicular waves in heifers. Journal of Reproduction and Fertility 94 177-188.

Austin EJ, Mihm M, Evans ACO, Knight PG, Ireland JLH, Ireland JJ \& Roche JF 2001 Alterations in intrafollicular regulatory factors and apoptosis during selection of follicles in the first follicular wave of the bovine estrous cycle. Biology of Reproduction 64 839-848.

Baerwald AR, Adams GP \& Pierson RA 2003a Characterization of ovarian follicular wave dynamics in women. Biology of Reproduction 69 1023-1031.

Baerwald AR, Adams GP \& Pierson RA $2003 \mathrm{~b}$ A new model for ovarian follicular development during the human menstrual cycle. Fertility and Sterility 80 116-122.

Bogoyevitch MA, Boehm I, Oakley A, Ketterman AJ \& Barr RK 2004 Targeting the JNK MAPK cascade for inhibition: basic science and therapeutic potential. Biochimica et Biophysica Acta (BBA) Proteins and Proteomics 1697 89-101.
Brunet A, Bonni A, Zigmond MJ, Lin MZ, Juo P, Hu LS, Anderson MJ, Arden KC, Blenis J \& Greenberg ME 1999 Akt promotes cell survival by phosphorylating and inhibiting a Forkhead transcription factor. Cell 96 857-868.

Canty MJ, Boland MP, Evans ACO \& Crowe MA 2005 Alterations in follicular IGFBP mRNA expression and follicular fluid IGFBP concentrations during the first follicle wave in beef heifers. Animal Reproduction Science 93 199-217.

Cardone MH, Roy N, Stennicke HR, Salvesen GS, Franke TF, Stanbridge E, Frisch S \& Reed JC 2000 Regulation of cell death protease caspase-9 by phosphorylation. Science 282 1318-1321.

Conti M 2002 Specificity of the cyclic adenosine $3^{\prime}, 5^{\prime}$-monophosphate signal in granulosa cell function. Biology of Reproduction 67 1653-1661.

Das S, Maizels ET, DeManno D, St Clair E, Adam SA \& HunzickerDunn M 1996 A stimulatory role of cyclic adenosine 3',5'monophosphate in follicle-stimulating hormone-activated mitogenactivated protein kinase signaling pathway in rat ovarian granulosa cells. Endocrinology 137 967-974.

Datta SR, Brunet A \& Greenberg ME 1999 Cellular survival: a play in three Akts. Genes Development 13 2905-2927.

Eul J, Meyer ME, Tora L, Bocquel MT, Quirin-Stricker C, Chambon P \& Gronemeyer H 1989 Expression of active hormone and DNAbinding domains of the chicken progesterone receptor in $E$. coli. EMBO Journal 8 83-90.

Evans ACO \& Fortune JE 1997 Selection of the dominant follicle in cattle occurs in the absence of differences in the expression of messenger ribonucleic acid for gonadotropin receptors. Endocrinology 138 2963-2971.

Evans ACO \& Martin F 2000 Kinase pathways in dominant and subordinate ovarian follicles during the first wave of follicular development in sheep. Animal Reproduction Science 64 221-231.

Evans ACO, Komar CM, Wandji SA \& Fortune JE 1997 Changes in androgen secretion and luteinizing hormone pulse amplitude are associated with the recruitment and growth of ovarian follicles during the luteal phase of the bovine estrous cycle. Biology of Reproduction 57 394-401.

Evans ACO, Ireland JLH, Winn ME, Lonergan P, Smith GW, Coussens PM \& Ireland JJ 2004 Identification of genes involved in apoptosis and dominant follicle development during follicular waves in cattle. Biology of Reproduction 70 1475-1484.

Fortune JE, Rivera GM \& Yang YM 2004 Follicular development: the role of the follicular microenvironment in selection of the dominant follicle. Animal Reproduction Science 82-83 109-126.

Gebauer G, Peter AT, Onesime D \& Dhanasekaran N 1999 Apoptosis of ovarian granulosa cells: correlation with the reduced activity of ERK-signaling module. Journal of Cellular Biochemistry 75 547-554.

Ginther OJ, Knopf L \& Kastelic JP 1989 Temporal associations among ovarian events in cattle during oestrous cycles with two and three follicular waves. Journal of Reproduction and Fertility 87 223-230.

Ginther OJ, Bergfelt DR, Kulick LJ \& Kot K 1998 Pulsatility of systemic $\mathrm{FSH}$ and $\mathrm{LH}$ concentrations during follicular-wave development in cattle. Theriogenology 50 507-519.

Ginther OJ, Bergfelt DR, Kulick LJ \& Kot K 1999 Selection of the dominant follicle in cattle: establishment of follicle deviation in less than $8 \mathrm{~h}$ through depression of FSH concentrations. Theriogenology 52 1079-1093.

Gong JG, Campbell BK, Bramley TA, Gutierrez CG, Peters AR \& Webb R 1996 Suppression in the secretion of follicle-stimulating hormone and luteinizing hormone, and ovarian follicle development in heifers continuously infused with a gonadotropin-releasing hormone agonist. Biology of Reproduction 55 68-74.

Gonzalez-Robayna IJ, Falender AE, Ochsner S, Firestone GL \& Richards JS 2000 Follicle-stimulating hormone (FSH) stimulates phosphorylation and activation of protein kinase B (PKB/Akt) and serum and glucocorticoid-induced kinase (Sgk): evidence for a kinase-independent signaling by FSH in granulosa cells. Molecular Endocrinology 14 1283-1300. 
Hu CL, Cowan RG, Harman RM \& Quirk SM 2004 Cell cycle progression and activation of Akt kinase are required for insulin-like growth factor I-medated suppression of apoptosis in granulosa cells. Molecular Endocrinology 18 326-328.

Ireland JJ, Murphee RL \& Coulson PB 1980 Accuracy of predicting stages of bovine estrous cycle by gross appearance of the corpus luteum. Journal of Dairy Science 63 155-160.

Kayampilly PP \& Menon KMJ 2004 Inhibition of extracellular signalregulated protein kinase-2 phosphorylation by dihydrotestosterone reduces follicle-stimulating hormone-mediated cyclin D2 messenger ribonucleic acid expression in rat granulosa cells. Endocrinology 145 1786-1793.

Lin A 2002 Activation of the JNK signaling pathway: breaking the brake on apoptosis. Bioassays 25 17-24.

Mihm M, Good TEM, Ireland JLH, Ireland JJ, Knight PG \& Roche JF 1997 Decline in serum follicle-stimulating hormone concentrations alters key intrafollicular growth factors involved in selection of the dominant follicle in heifers. Biology of Reproduction 57 1328-1337.

Mihm M, Austin EJ, Good TEM, Ireland JLH, Knight PG, Roche JF \& Ireland JJ 2000 Identification of potential intrafollicular factors involved in selection of dominant follicles in heifers. Biology of Reproduction 63 811-819.

Minegishi T, Hirakawa T, Kishi H, Abe K, Abe Y, Mizutani T \& Miyamoto K 2000 A role of insulin-like growth factor i for folliclestimulating hormone receptor expression in rat granulosa cells. Biology of Reproduction 62 325-333.

Pearson G, Robinson F, Beers Gibson T, Xu BE, Karandikar M, Berman K \& Cobb MH 2001 Mitogen-activated protein (MAP) kinase pathways: regulation and physiological functions. Endocrine Reviews 22 153-183.

Peter A \& Dhanasekaran N 2003 Apoptosis of granulosa cells: a review on the role of MAPK-signalling modules. Reproduction in Domestic Animals 38 209-213.
Prendiville DJ, Enright WJ, Crowe MA, Finnerty M, Hynes N \& Roche JF 1995 Immunization of heifers against gonadotropin-releasing hormone: antibody titers, ovarian function, body growth, and carcass characteristics. Journal of Animal Science 73 2382-2389.

Roux PP \& Blenis J 2004 ERK and p38 MAPK-activated protein kinases: a family of protein kinases with diverse biological functions. Microbiology and Molecular Biology Reviews 68 320-344.

Savio JD, Keenan L, Boland MP \& Roche JF 1988 Pattern of growth of dominant follicles during the oestrous cycle of heifers. Journal of Reproduction and Fertility 83 663-671.

Shiota M, Sugai N, Tamura M, Yamaguchi R, Fukushima N, Miyano T \& Miyazaki H 2003 Correlation of mitogen-activated protein kinase activities with cell survival and apoptosis in porcine granulosa cells. Zoological Science 20 193-201.

Sirois J \& Fortune JE 1988 Ovarian follicular dynamics during the estrous cycle in heifers monitored by real-time ultrasonography. Biology of Reproduction 39 308-317.

Yang MY \& Rajamahendran R 2000 Morphological and biochemical identification of apoptosis in small, medium, and large bovine follicles and the effects of follicle-stimulating hormone and insulinlike growth factor-i on spontaneous apoptosis in cultured bovine granulosa cells. Biology of Reproduction 62 1209-1217.

Zhang W \& Liu HT 2002 MAPK signal pathways in the regulation of cell proliferation in mammalian cells. Cell Research 12 9-18.

Received 2 August 2006

First decision 2 October 2006

Revised manuscript received 19 December 2006

Accepted 21 December 2006 